\title{
Horizontal and vertical distributions of siphonophores in relation to oceanographic conditions in Chilean Patagonian fjords
}

\author{
Sergio Palma ${ }^{1}$, María Cristina Retamal ${ }^{1,2}$, Nelson Silva ${ }^{1}$, Claudio Silva ${ }^{1}$ \\ ${ }^{1}$ Escuela de Ciencias del Mar, Pontificia Universidad Católica de Valparaíso, P.O. Box 1020, Valparaíso, Chile. \\ E-mail: spalma@ucv.cl \\ ${ }^{2}$ Servicio Hidrográfico y Oceanográfico de la Armada, P.O. Box 324, Valparaíso, Chile.
}

\begin{abstract}
Summary: Siphonophores collected in Chilean Patagonian fjords, between the Gulf of Penas and the Trinidad Channel in 2008 were analysed. A total of 12 species were recorded, of which Muggiaea bargmannae, Lensia subtilis, Praya dubia and Sphaeronectes fragilis were identified for the first time in this sector of the Patagonian fjords. M. bargmannae represents a new record for the southeastern Pacific. The most abundant species were Muggiaea atlantica (78.6\%), Lensia conoidea $(8.7 \%)$ and Dimophyes arctica (8.5\%). M. atlantica, the dominant species, showed high densities in both oceanic and interior waters. $L$. conoidea and $D$. arctica, on the other hand, were principally collected in interior waters. M. atlantica was collected in less saline $(<30)$, more oxygenated $\left(6-7 \mathrm{~mL} \mathrm{~L}^{-1}\right)$ shallow strata $(0-50 \mathrm{~m})$, while $L$. conoidea and $D$. arctica were collected below $50 \mathrm{~m}$ depth in more saline (30-33) and less oxygenated $\left(4-6 \mathrm{~mL} \mathrm{~L}^{-1}\right)$ waters. The eudoxids of these species followed the same horizontal and vertical distribution patterns as their polygastric stages. These results confirm the success of $M$. atlantica in the colonization of all the southern fjords and document an increase with respect to the results obtained for the same geographical area in the spring of 1996. They also allowed us to infer that salinity and dissolved oxygen vertical gradients play an important role in determining the depth distribution patterns of these species.
\end{abstract}

Keywords: siphonophores; gelatinous zooplankton; horizontal distribution; vertical distribution; Chilean Patagonian fjords.

Distribución horizontal y vertical de los sifonóforos en relación con las condiciones oceanográficas en fiordos patagónicos chilenos

Resumen: Se analizaron los sifonóforos muestreados en fiordos patagónicos chilenos, entre el golfo de Penas y canal Trinidad en primavera de 2008. Se identificó un total de 12 especies, de las cuales Muggiaea bargmannae, Lensia subtilis, Praya dubia y Sphaeronectes fragilis fueron registrados por primera vez en este sector de fiordos patagónicos. M. bargmannae constituye un nuevo registro de sifonóforos en el Pacífico suroriental. Las especies más abundantes fueron Muggiaea atlantica (78.6\%), Lensia conoidea $(8.7 \%)$ y Dimophyes arctica $(8.5 \%)$. M. atlantica, la especie dominante, mostró altas densidades tanto en aguas oceánicas como interiores. Por otra parte, L. conoidea y $D$. arctica se colectaron principalmente en aguas interiores. Las eudoxias de estas especies siguieron los mismos patrones de distribución horizontal que sus fases poligástricas. $M$. atlantica se encontró en aguas menos salinas $(<30)$ y más oxigenadas $\left(6-7 \mathrm{~mL} \mathrm{~L}^{-1}\right)$ en el estrato superficial $(0-50 \mathrm{~m})$, mientras que $L$. conoidea y $D$. arctica se colectaron bajo los $50 \mathrm{~m}$ de profundidad en aguas más salinas (30-33) y menos oxigenadas (4-6 mL L ${ }^{-1}$ ). Estos resultados confirman el éxito de $M$. atlantica en la colonización de todos los fiordos australes y su incremento respecto a resultados obtenidos en la misma área geográfica en primavera de 1996.

Palabras clave: sifonóforos; zooplancton gelatinoso; distribución horizontal; distribución vertical; fiordos patagónicos chilenos.

Citation/Como citar este artículo: Palma S., Retamal M.C., Silva N., Silva C. 2014. Horizontal and vertical distributions of siphonophores in relation to oceanographic conditions in Chilean Patagonian fjords. Sci. Mar. 78(3): 339-351. doi: http:// dx.doi.org/10.3989/scimar.03966.04B

Editor: D. Lindsay.

Received: October 7, 2013. Accepted: June 30, 2014. Published: August 4, 2014.

Copyright: () 2014 CSIC. This is an open-access article distributed under the Creative Commons Attribution-Non Commercial Lisence (by-nc) Spain 3.0. 


\section{INTRODUCTION}

A steady increase in gelatinous predator populations in marine ecosystems has been observed in recent years, and this has promoted studies on gelatinous macroplankton due to their significance in determining marine ecosystem structure (Mills 2001, Brodeur et al. 2002, Purcell et al. 2007). Such predators include the siphonophores, a widespread and abundant group that are found in coastal and oceanic waters and play a critical ecological role as competitors and predators of other zooplankters, particularly micro-crustaceans and marine invertebrate and vertebrate larval stages (Mackie et al. 1987, Pugh 1999). Siphonophores have a polymorphic colony structure, with a life cycle allowing them to produce high quantities of the sexual stage (eudoxids in the Calycophorae), thus generating large population densities during some periods of the year, particularly in highly productive biological areas (Pugh 1999, Palma and Apablaza 2004, Thibault-Botha et al. 2004, Pavez et al. 2010).

Siphonophore communities have been studied in diverse geographical areas bathed by the Humboldt Current System in Chilean coastal waters, particularly in coastal areas of upwelling such as Antofagasta, Valparaíso and Concepción, where common species (e.g. Muggiaea atlantica and Sphaeronectes koellikeri) can reach high population densities during spring and summer (Palma 1994, Palma and Rosales 1995, Pagès et al. 2001, Palma and Apablaza 2004, Apablaza and Palma 2006, Pavez et al. 2010). M. atlantica also commonly inhabits Chilean Patagonian fjords and channels and is a dominant species in this southern region (Palma and Silva 2004, Villenas et al. 2009, Palma et al. 2007a, 2011).

The Chilean Patagonian fjords form one of the most extensive estuarine areas in the world, extending from

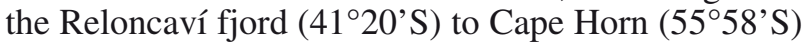
and including areas of complex geomorphology and oceanography. They are approximately $1600 \mathrm{~km}$ long and cover a total area of $240000 \mathrm{~km}^{2}$ (Palma and Silva 2004). This ecosystem involves a two-layer estuarine circulation system: a surface layer (from the surface to 20-30 m depth) of Estuarine Water (EW) flowing towards the adjacent ocean, with low salinity due to freshwater discharge, high annual precipitation and coastal runoff; and a deeper layer (20-30 m to the bottom), which is more saline, colder and of higher density as a result of the inward flow of the Subantarctic Water (SAAW). A strong halocline develops between the two layers and, therefore, a pycnocline forms at 20-30 m depth, thus generating a highly stratified system (Silva and Calvete 2002).

The ecosystem of the interior waters, located between the Reloncaví Fjord and the Elefantes Gulf (46 $\left.30^{\circ} \mathrm{S}\right)$, has been intensively studied during the last two decades because of activities associated with marine transportation, tourism, fisheries and aquaculture (Buschmann et al. 2006, Silva and Palma 2008). Thus, numerous oceanographic and biological studies have been carried out in this zone (Silva and Palma 2008), including studies on siphonophores and jellyfish with results showing that the two-layer hydrographic struc- ture may affect not only the species composition but also the vertical distribution of the zooplankton in interior waters (Palma et al. 2007a, 2007b, 2011, Villenas et al. 2009, Bravo et al. 2011).

In contrast, the fjord ecosystem located between the Gulf of Penas $\left(47^{\circ} \mathrm{S}\right)$ and Cape Horn has received little attention. In this vast area, the sector covering the Gulf of Penas and the Trinidad Channel (50 $\left.10^{\circ} \mathrm{S}\right)$ has been barely studied and published works on zooplankton are restricted to reports on siphonophores, chaetognaths, euphausiids and cladocerans (Palma et al. 1999, Rosenberg and Palma 2003), ichthyoplankton (Bustos et al. 2011) and decapod crustacean larvae (Mujica and Medina 2000). This southern area receives Subantarctic Water input from the adjacent Pacific, entering through the Gulf of Penas $(0-150 \mathrm{~m})$ to the north, the Ladrillero Gulf (0-50 m) in the centre and the Trinidad Gulf (0-70 $\mathrm{m})$ to the south. These highly saline subantarctic waters merge with freshwater from rivers, such as the Baker $\left(870 \mathrm{~m}^{3} \mathrm{~s}^{-1}\right)$ and Pascua $\left(574 \mathrm{~m}^{3} \mathrm{~s}^{-1}\right)$ Rivers and melt water from the Southern Ice Field, thus forming EW flowing seawards in the upper 25-30 m depth stratum (Silva and Calvete 2002, Calvete and Sobarzo 2011).

This work analyses the effect of water column stratification on the spatial distribution of the polygastric and eudoxid stages of siphonophores in the central Patagonian fjords of southern Chile $\left(47^{\circ}-50^{\circ} 10^{\prime} \mathrm{S}\right)$.

\section{MATERIALS AND METHODS}

A total of 40 oceanographic stations were occupied during the CIMAR 14 Fiordos cruise performed between 25 October and 24 November 2008, and these were distributed between the Gulf of Penas $\left(47^{\circ} \mathrm{S}\right)$ and the Trinidad Channel (50¹0'S) (Fig. 1). Only the sampling stations situated along two longitudinal transects were considered in the vertical distribution analysis. The oceanic transect (OT, 10 stations) comprised the Gulf of Penas and the Fallos, Ladrillero, Picton and Trinidad Channels, and included the stations with the highest adjacent oceanic water input. The estuarine transect (ET, 9 stations), on the other hand, involved the Gulf of Penas and the Messier, Paso del Indio and Wide Channels and the stations with the highest EW input (Fig. 1).

A CTDO Sea-Bird model SBE 25 was used at each station to record the oceanographic variables of temperature, salinity and dissolved oxygen content in the water column. Salinity and dissolved oxygen records were corrected using the results from instrumental (salinometer) and chemical (Winkler) analyses of discrete samples collected in the water column during the CTDO casting.

Zooplankton samples were obtained by oblique tows in three strata: surface (0-25 $\mathrm{m}$ at 40 stations), middle (25-50 m at 40 stations) and deep (50-200 m or $50 \mathrm{~m}$-near bottom, depending on bottom depth at 28 stations), during day and night. The strata were selected considering the two-layer oceanographic structure characterizing the interior region of the fjords and channels (Silva and Calvete 2002). The sampling gear was a Tucker trawl net (1- $\mathrm{m}^{2}$ mouth opening and 350- 


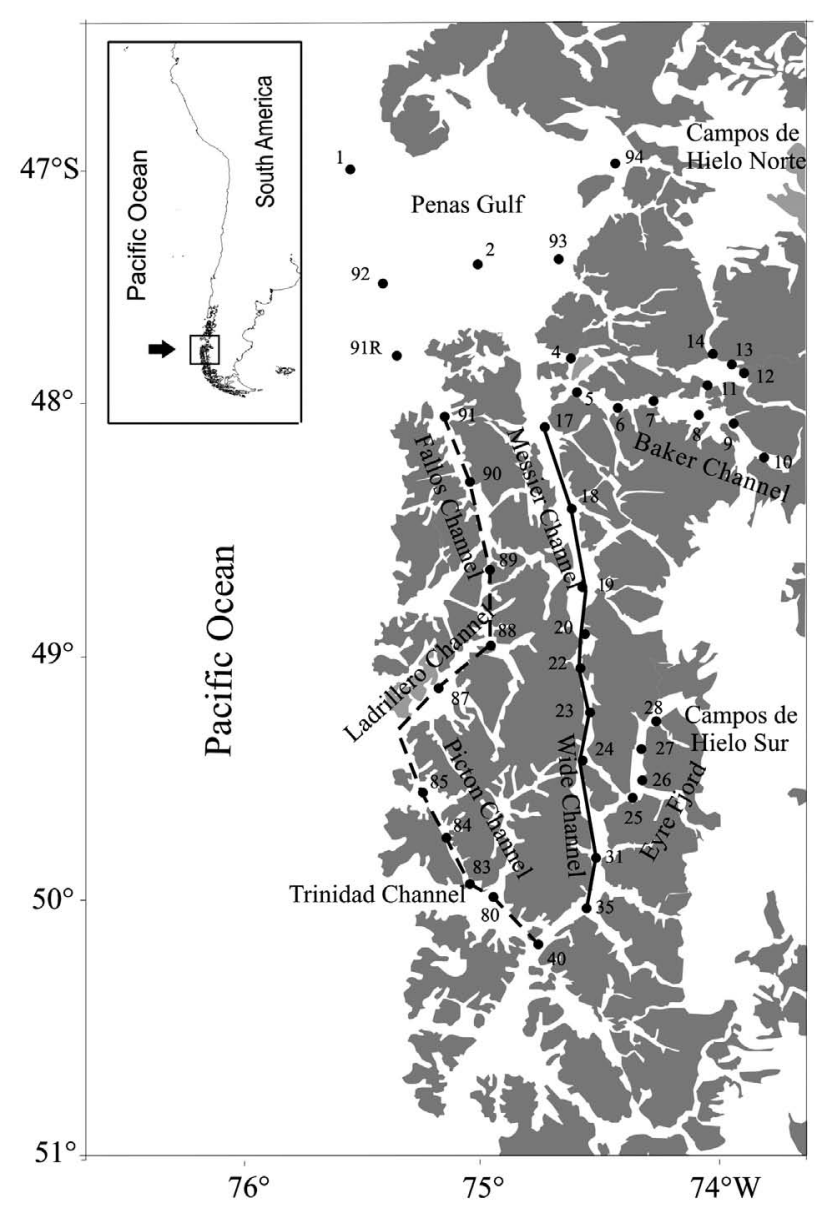

Fig. 1. - Geographic positions of sampling stations between Penas Gulf and Trinidad Channel (CIMAR 14 Fiordos cruise). Dashed line, oceanic transect (OT); solid line, estuarine transect (ET).

$\mu \mathrm{m}$ mesh aperture), which included a two-net system provided with a digital flowmeter in order to estimate the volume filtered by each net. Zooplankton samples were fixed immediately after collection and preserved in $5 \%$ formalin-seawater buffered with sodium borate.

A total of 108 vertically stratified samples were examined. The siphonophores were sorted from the original samples, and the nectophores (asexual polygastric stage) and eudoxids (sexual eudoxid stage) were identified and counted. The abundances of Calycophorae were estimated considering the highest number of anterior or posterior nectophores. Pyrostephos vanhoeffeni was the only species of the Physonectae collected, and its abundance was estimated by considering one individual to have 20 pairs of nectophores per colony (Totton 1965). The taxonomic identification of siphonophore species followed the works of Totton (1965) and Pugh (1999). Polygastric and eudoxid stages for the whole column were converted for every stage to density (ind $1000 \mathrm{~m}^{-3}$ ), using the volume of water filtered by the nets. Only the dominant species ( $>5 \%$ of the total of individuals) were considered when characterizing the horizontal and vertical distribution patterns. Vertical distributions, using the normalized data, were expressed according to the percentage of individuals in each stratum compared to the total number of individuals collected from the entire water column; and dif- ferences in the vertical distributions in depth strata at sampling stations were tested by a Kruskal-Wallis test. The relationship between the distribution patterns of siphonophore abundances and oceanographic physical and chemical features over the sampling stations were explored using a canonical correspondence analysis (CCA; Ter Braak and Verdonschot 1995). The level of significance was set at $\mathrm{p}<0.05$. Initial analysis included abundance data for 11 dominant faunal and 4 environmental variables (depth strata, temperature, salinity and dissolved oxygen). The Monte Carlo permutation test (with 999 unrestricted permutations) was used to determine the significance of fauna-environment relationships. The CCA analysis was performed using XLStat software (version 2011.4.04, Addinsoft).

\section{RESULTS}

\section{Hydrographic characteristics}

The surface temperatures in the Baker Fjord (not shown) were almost uniform from its mouth to its head $\left(\sim 9^{\circ} \mathrm{C}\right)$; in the Eyre Fjord (not shown), however, they decreased from its mouth $\left(\sim 8^{\circ} \mathrm{C}\right)$ to its head $\left(\sim 7^{\circ} \mathrm{C}\right)$. The water column was almost homothermal $\left(\sim 8^{\circ} \mathrm{C}\right)$ below $50 \mathrm{~m}$ in both fjords, while the whole water column was almost homothermal in the oceanic and longitudinal transects. Surface temperatures for the interior channels were around $8^{\circ} \mathrm{C}-9^{\circ} \mathrm{C}$ and around $9^{\circ} \mathrm{C}-10^{\circ} \mathrm{C}$ for the external channels (Fig. 2A and D). The highest surface temperature values were observed in the Gulf of Penas, at the northern extreme of both longitudinal transects. The lowest surface temperature values in the ET were observed near the middle of Angostura Inglesa and in the OT, at the southernmost end of the Concepción Channel. Below $200 \mathrm{~m}$ the temperature of the deep layer was almost homothermal in every single micro basin $\left(\sim 8^{\circ} \mathrm{C}\right)$.

The surface salinity in the Baker and Eyre Fjords decreased from their mouths to their heads ( 28 to 2 and 26 to 24, respectively). Both fjords had a highly stratified low salinity (20-33) surface layer $(\sim 50 \mathrm{~m})$, giving rise to strong haloclines above $50 \mathrm{~m}$ (Fig. 2B and E). The water column below $50 \mathrm{~m}$ was almost homogeneous, with salinities around 33-34 in the Baker Fjord and 32-33 in the Eyre Fjord. In the ET transect, the lowest surface salinity values occurred near Angostura Inglesa $(<24)$, Wide Channel $(<20)$, in the OT transect and in the Fallos-Ladrillero channels $(<26)$. A highly stratified low salinity (20-33) surface layer $(\sim 50 \mathrm{~m})$ occurred in both transects, giving rise to strong haloclines. The depth of the bottom of the halocline generally coincided with the 32 salinity isopleth, which was at around $50 \mathrm{~m}$ depth. Below this highly stratified surface layer (i.e. $>50 \mathrm{~m}$ ), the water column was saltier (32-34) and almost homogeneous.

Dissolved oxygen concentration in the Baker and Eyre Fjords was almost homogeneous in the surface layer $(\sim 0-10 \mathrm{~m})$ from mouth to head $\left(\sim 7 \mathrm{~mL} \mathrm{~L}^{-1}\right)$. Below this well-oxygenated surface layer, dissolved oxygen decreased to around $3 \mathrm{~mL} \mathrm{~L}^{-1}$ in the Baker Fjord and to around $4 \mathrm{~mL} \mathrm{~L}^{-1}$ in the Eyre Fjord. In both longitudinal 


\section{Oceanic transect}

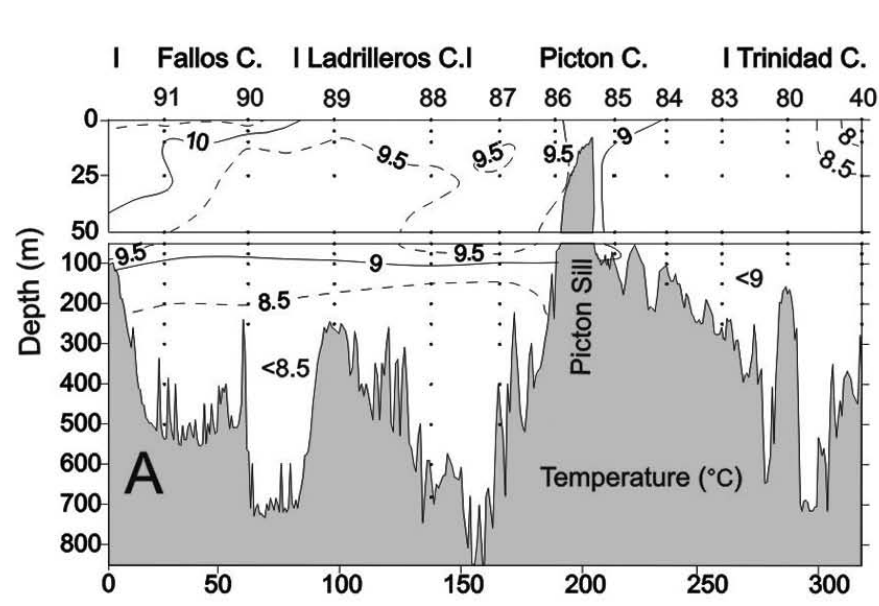

\section{Estuarine transect}

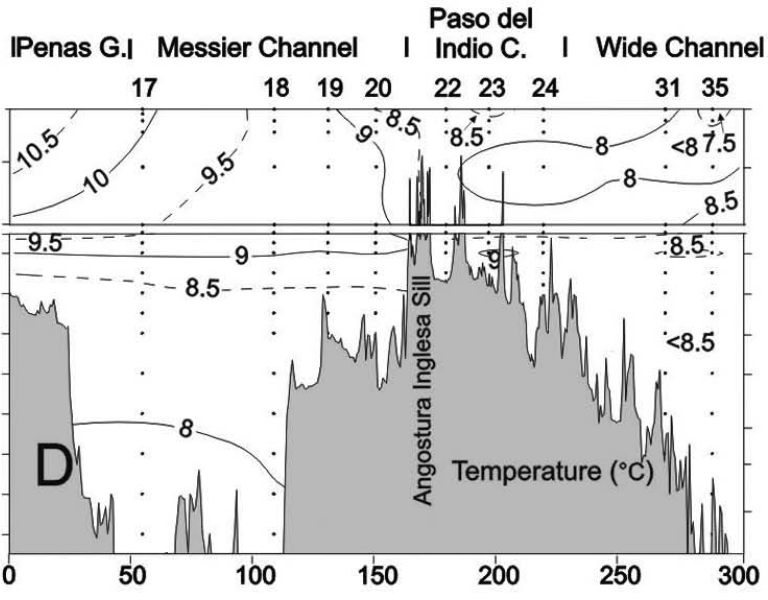

Paso de

I Fallos C. I Ladrilleros C.I Picton C. I Trinidad C. IPenas G.I Messier Channel I Indio C. I Wide Channel
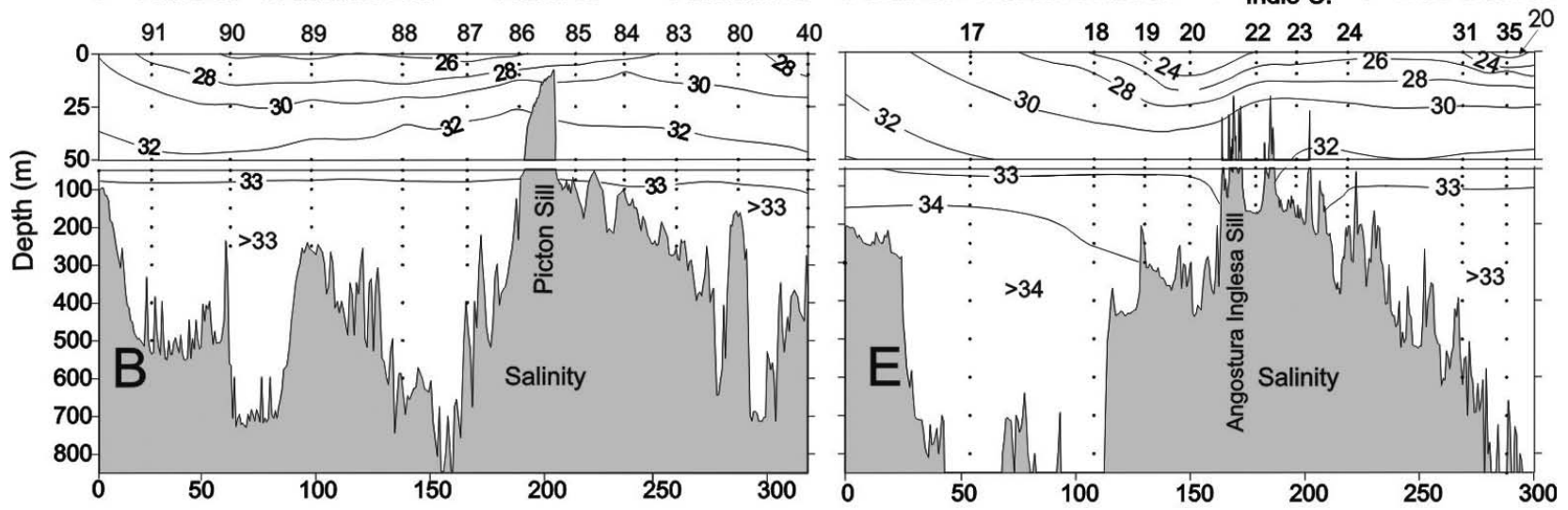

I Fallos C. I Ladrilleros C.I Picton C. I Trinidad C.
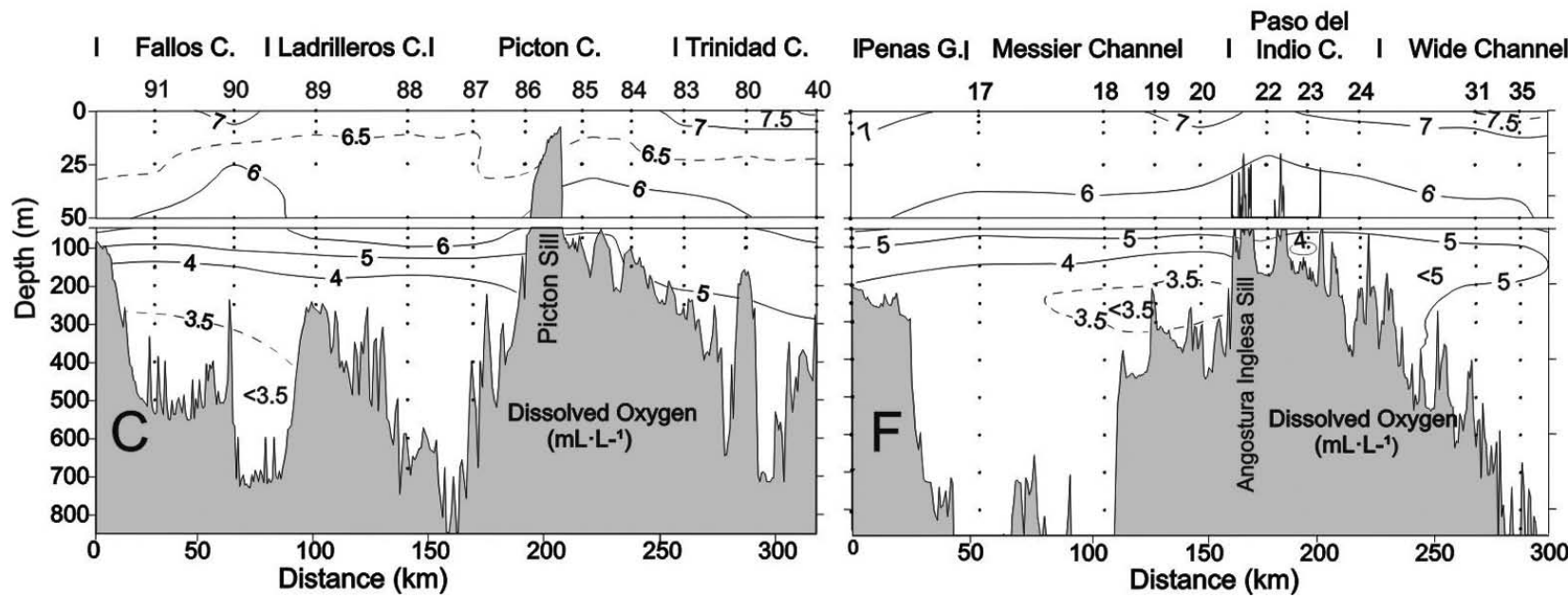

Fig. 2. - Vertical distribution of temperature (A), salinity (B) and dissolved oxygen (C) in the longitudinal oceanic transect (OT) and temperature (D), salinity (E) and dissolved oxygen (F) in the longitudinal estuarine transect (ET) between Penas Gulf and Trinidad Channel in spring 2008.

transects (Fig. 2C and F) the surface layer ( 0-50 m) had a nearly homogeneous high dissolved oxygen content $\left(>6 \mathrm{~mL} \mathrm{~L}^{-1}\right.$ ). Below this layer, the dissolved oxygen decreased rapidly to $4 \mathrm{~mL} \mathrm{~L}^{-1}$ at around $100 \mathrm{~m}$. In the deep layer of both transects the dissolved oxygen concentrations decreased below $3.5 \mathrm{~mL} \mathrm{~L}^{-1}$ in the northern micro basin and below $5 \mathrm{~mL} \mathrm{~L}^{-1}$ in the southern micro basin.

\section{Specific composition}

A total of 12 species of siphonophores (polygastric and eudoxid stages), 11 calycophorans and one physonect were identified. The total number of collected organisms, abundance ranges, average abundance, dominance and occurrence data are shown in 
Table 1. - Summary of basic statistics for polygastric (po) and eudoxid or sexual (eu) stages of siphonophores. Total number of individuals, range of abundances, average per station, dominance and occurrence. Abundances are expressed as ind $1000 \mathrm{~m}^{-3}$. $\mathrm{Ne}, \mathrm{nectophores;} \mathrm{Sg}$, stem group.

\begin{tabular}{|c|c|c|c|c|c|c|}
\hline Species & Life stage & Total number & $\begin{array}{c}\text { Range of } \\
\text { non-zero } \\
\text { abundances }\end{array}$ & $\begin{array}{c}\text { Average } \\
\text { abundance }\end{array}$ & Dominance $(\%)$ & Occurrence $(\%)$ \\
\hline \multirow[t]{2}{*}{ Muggiaea atlantica } & $\mathrm{Po}$ & 124752 & $14-38174$ & 3118.8 & 78.62 & 100 \\
\hline & $\mathrm{Eu}$ & 95078 & $10-50136$ & 2376.9 & 63.44 & 88 \\
\hline \multirow[t]{2}{*}{ Lensia conoidea } & $\mathrm{Po}$ & 13854 & $6-3500$ & 346.3 & 8.73 & 88 \\
\hline & $\mathrm{Eu}$ & 13631 & 4-3707 & 340.8 & 9.10 & 83 \\
\hline \multirow{2}{*}{ Dimophyes arctica } & Po & 13428 & $13-2685$ & 335.7 & 8.46 & 90 \\
\hline & $\mathrm{Eu}$ & 36685 & $18-6455$ & 917.1 & 24.48 & 93 \\
\hline Pyrostephos vanhoeffeni & $\mathrm{Ne}$ & 2882 & $1-427$ & 72.0 & 1.82 & 70 \\
\hline Lensia meteori & Po & 1535 & $3-419$ & 38.4 & 0.97 & 58 \\
\hline Sphaeronectes koellikeri & Po & 847 & $3-289$ & 21.2 & 0.53 & 25 \\
\hline Sphaeronectes fragilis & Po & 627 & $4-228$ & 15.7 & 0.40 & 25 \\
\hline Lensia subtilis & Po & 391 & $13-186$ & 9.8 & 0.25 & 10 \\
\hline \multirow[t]{2}{*}{ Eudoxoides spiralis } & Po & 320 & $6-107$ & 8.0 & 0.20 & 20 \\
\hline & $\mathrm{Eu}$ & 4466 & $10-2202$ & 111.7 & 2.98 & 48 \\
\hline Muggiaea bargmannae & $\mathrm{Po}$ & 21 & $1-21$ & 0.5 & 0.01 & 3 \\
\hline Chelophyes appendiculata & Po & 13 & $1-13$ & 0.3 & 0.01 & 3 \\
\hline Praya dubia & $\mathrm{Sg}$ & 2 & $1-1$ & 0 & 0 & 5 \\
\hline
\end{tabular}

Table 2. - Summary of basic statistics for polygastric stage abundances (ind $1000 \mathrm{~m}^{-3}$ ) between the oceanic and estuarine transects. Range of non-zero abundances, average abundance per station, dominance and occurrence.

\begin{tabular}{|c|c|c|c|c|c|c|c|c|}
\hline \multirow[b]{2}{*}{ Species } & \multicolumn{4}{|c|}{ Oceanic Transect } & \multicolumn{4}{|c|}{ Estuarine Transect } \\
\hline & $\begin{array}{c}\text { Range of } \\
\text { non-zero } \\
\text { abundances }\end{array}$ & $\begin{array}{l}\text { Average per } \\
\text { station }\end{array}$ & $\begin{array}{c}\text { Dominance } \\
(\%)\end{array}$ & $\begin{array}{l}\text { Occurrence } \\
(\%)\end{array}$ & $\begin{array}{c}\text { Range of } \\
\text { non-zero } \\
\text { abundances }\end{array}$ & $\begin{array}{l}\text { Average per } \\
\text { station }\end{array}$ & $\begin{array}{c}\text { Dominance } \\
(\%)\end{array}$ & $\begin{array}{c}\text { Occurrence } \\
(\%)\end{array}$ \\
\hline Muggiaea atlantica & $8-2132$ & 992.0 & 47.0 & 100 & $436-38174$ & 7567.4 & 90.7 & 100 \\
\hline Lensia conoidea & $5-3499$ & 685.4 & 32.5 & 100 & $17-995$ & 402.0 & 4.8 & 100 \\
\hline Dimophyes arctica & $53-1611$ & 337.3 & 16.0 & 100 & $58-661$ & 222.3 & 2.7 & 90 \\
\hline Pyrostephos vanhoeffeni & $3-218$ & 43.2 & 2.0 & 60 & $3-404$ & 86.5 & 1.0 & 80 \\
\hline Sphaeronectes fragilis & $8-227$ & 37.1 & 1.8 & 30 & $3-162$ & 19.8 & 0.2 & 30 \\
\hline Lensia meteori & $8-38$ & 11.6 & 0.5 & 60 & $6-75$ & 17.6 & 0.2 & 50 \\
\hline Sphaeronectes koellikeri & $5-8$ & 2.0 & 0.1 & 30 & $16-241$ & 28.6 & 0.3 & 30 \\
\hline
\end{tabular}

Table 1. The calycophorans Muggiaea bargmannae, Lensia subtilis, Praya dubia and Sphaeronectes fragilis are recorded for the first time in this central Chilean Patagonian area (47-50 $\mathrm{S})$. The presence of four nectophores of M. bargmannae in the Picton Channel (Sta. 88) represents the first record of this species in Chilean waters. L. subtilis and S. fragilis were collected from several stations; meanwhile, $P$. dubia was only represented by two stem groups collected in the Baker Fjord (stations 4 and 6). The dominant gelatinous species in terms of relative abundances were Muggiaea atlantica (78.6\% of the total number of polygastric stages), Lensia conoidea (8.7\%) and Dimophyes arctica (8.5\%), while the remaining species were only found occasionally (Table 1). In decreasing order, the most commonly occurring species were $M$. atlantica (100\% of stations), D. arctica (90\% of stations) and L. conoidea ( $88 \%$ of stations).

\section{Horizontal distribution}

The abundances of siphonophores ranged between 35 and 39140 ind $1000 \mathrm{~m}^{-3}$ in the Picton and Messier channels (stations 87 and 22, respectively). $M$. atlantica occurred with a minimum abundance of 14 ind $1000 \mathrm{~m}^{-3}$ (station 14) in the Baker Channel, and a maximum of 38174 ind $1000 \mathrm{~m}^{-3}$ (station 22) in the Messier Channel (Fig. 3A). The highest densities were found in the Gulf of Penas (oceanic waters), the Messier Channel and the Eyre Fjord (interior waters). Intermediate densities were obtained in the oceanic channels (Fallos, Ladrillero, Picton and Trinidad) and the lowest density was found in the Baker Channel, where the salinity fluctuated between 5 and 33 in the upper $100 \mathrm{~m}$. Lensia conoidea and Dimophyes arctica showed a very similar spatial distribution, with maxima in the Eyre Fjord and at some stations in the Messier and Trinidad channels (Fig. 3B-C). The most significant difference between the two species was found in the Gulf of Penas, where L. conoidea was almost absent, and $D$. arctica was collected at most stations, being concentrated at the mouth of the gulf.

The eudoxids of $M$. atlantica, L. conoidea and $D$. arctica were always more numerous than the polygastric stages. These eudoxids followed the same patterns of geographic distribution as the polygastric stages. Eudoxids of $M$. atlantica also exhibited abundance maxima in the Gulf of Penas and Messier Channel (Fig. 3D). Maximum concentrations of the eudoxids of $L$. conoidea were found in the Trinidad Channel and of D. arctica in this same channel and in the Eyre Fjord (Fig. 3E-F). It is worth mentioning that in the Gulf of Penas, where highly saline waters (ASAA) predominated, only $M$. atlantica eudoxids were abundant, with both $L$. conoidea and D. arctica being extremely rare.

The abundance of polygastric stages of $M$. atlantica (Table 2) exhibited significant differences between the two transects $(p<0.05)$, with a higher dominance in the ET $(90.7 \%)$ than in the OT $(47.0 \%)$. This difference in abundance was also observed for rarer species, 

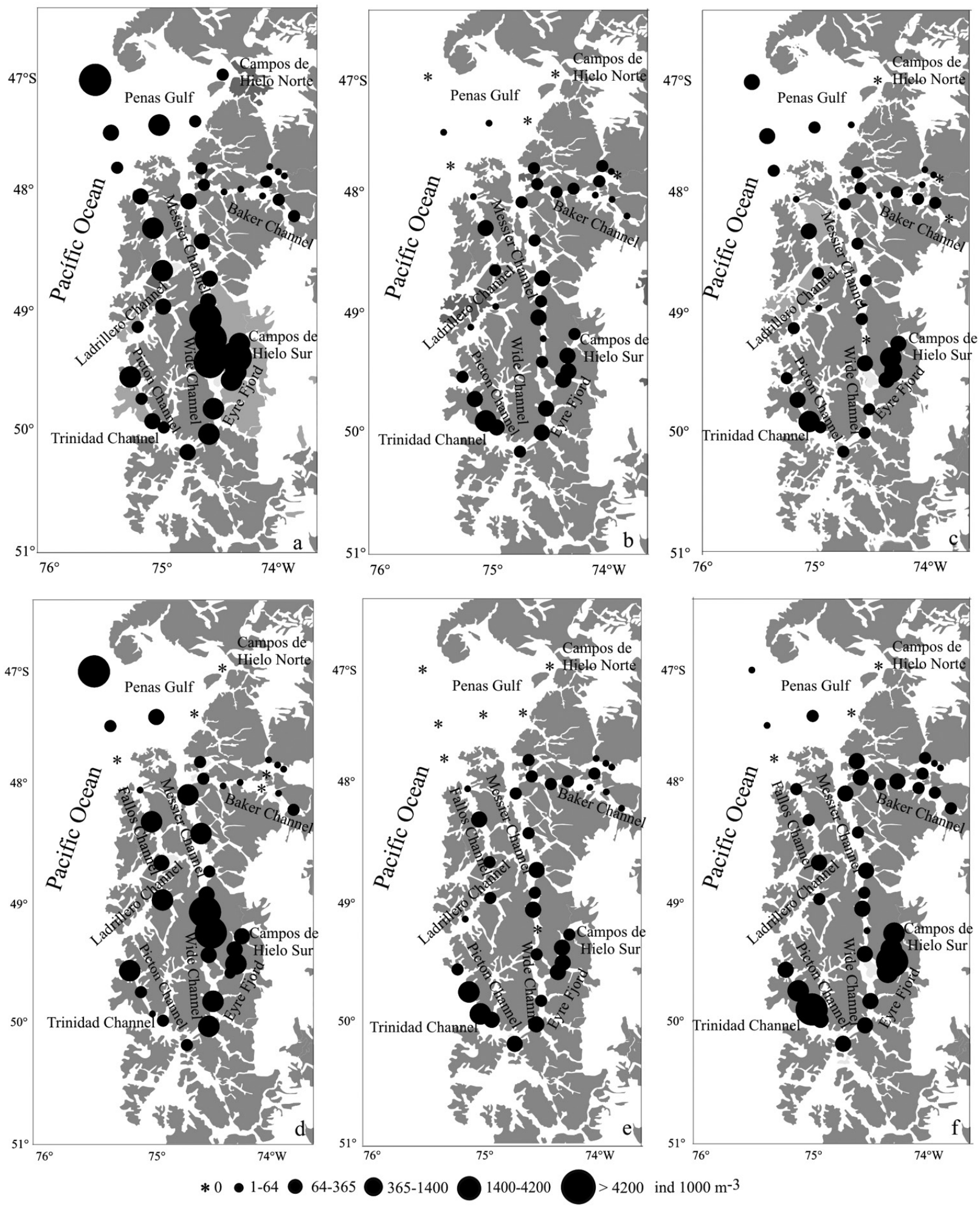

Fig. 3. - Spatial distribution in spring 2008 of polygastric stages of Muggiaea atlantica (A), Lensia conoidea (B), Dimophyes arctica (C), and eudoxids of M. atlantica (D), L. conoidea (E) and D. $\operatorname{arctica}(\mathrm{F})$.

such as Pyrostephos vanhoeffeni, Lensia meteori and Sphaeronectes koellikeri (Table 2). Lensia conoidea and $D$. arctica also showed significant differences in abundance between the two transects $(\mathrm{p}<0.05)$; however, their maxima occurred in the OT, with dominance values of $32.5 \%$ and $16 \%$, respectively - a trend also apparent in S. fragilis (Table 2).

\section{Vertical distribution in OTs and ETs}

The dominant species showed two kinds of vertical distribution patterns. Muggiaea atlantica was found throughout the water column, the highest densities always being found in the upper $50 \mathrm{~m}$, except at station 2 in the Gulf of Penas, where the greatest numbers were found be- 


\section{Oceanic transect}

\section{Estuarine transect}

Paso del

I Fallos C. I Ladrilleros C.I Picton C. I Trinidad C. IPenas G.I Messier Channel I Indio C. IWide Channel
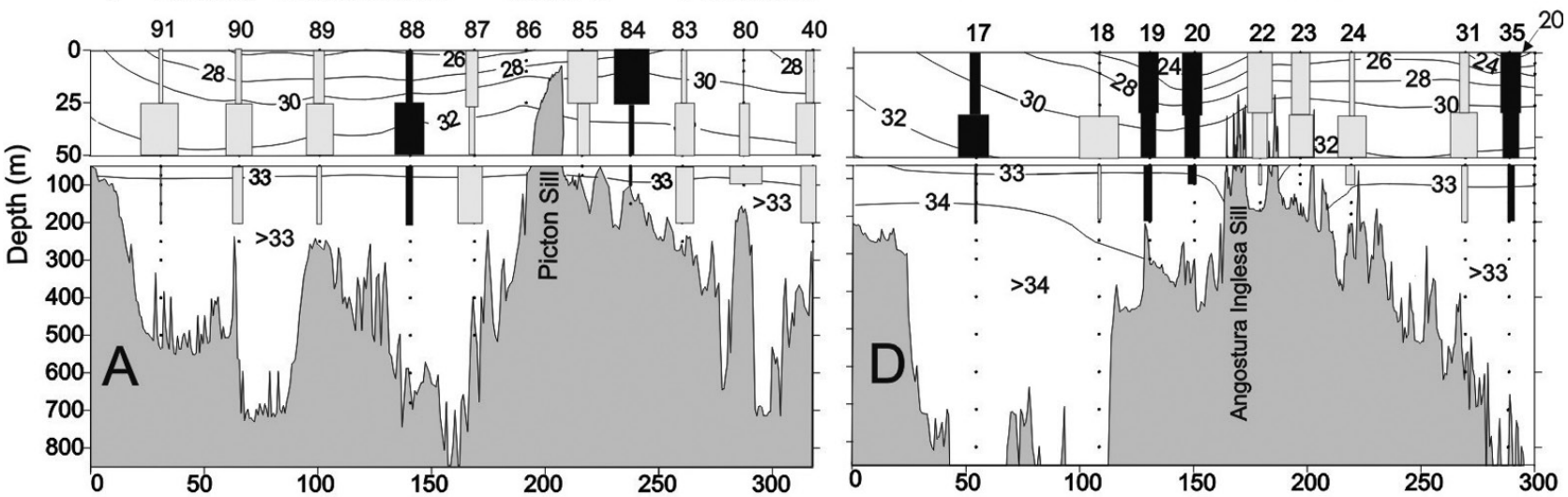

Paso del

I Fallos C. I Ladrilleros C.I Picton C.

I Trinidad C.
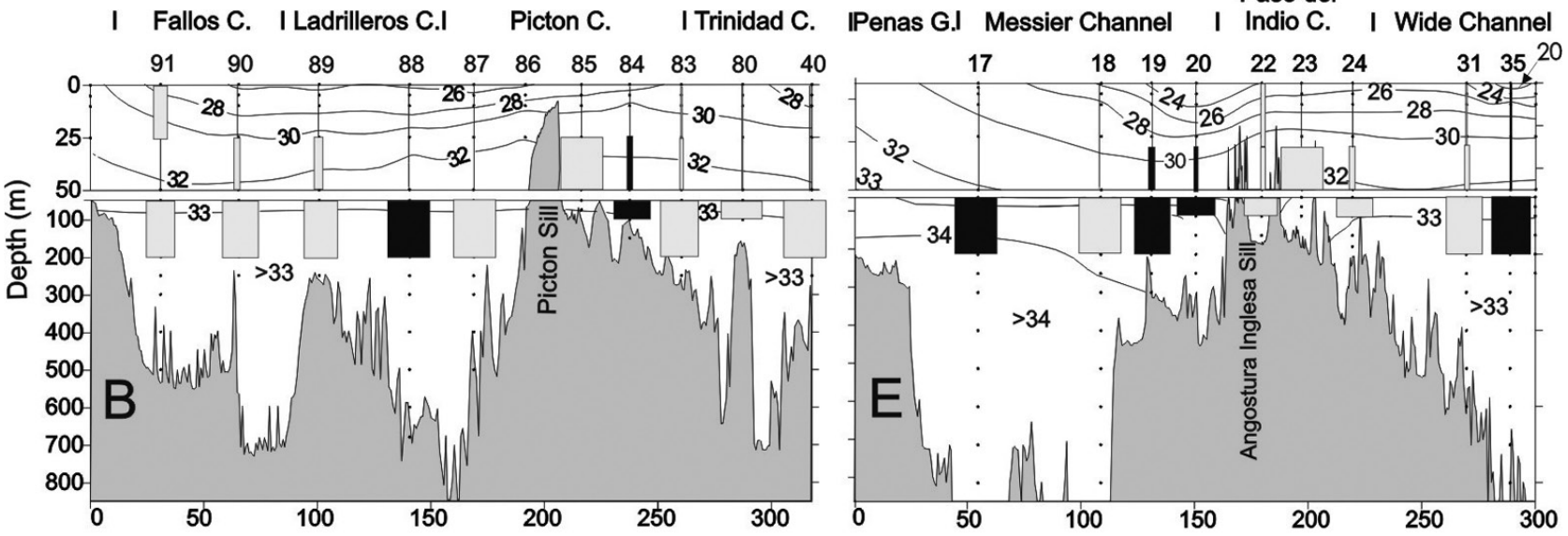

I Fallos C. I Ladrilleros C.I Picton C. I Trinidad C. IPenas GI Maso del
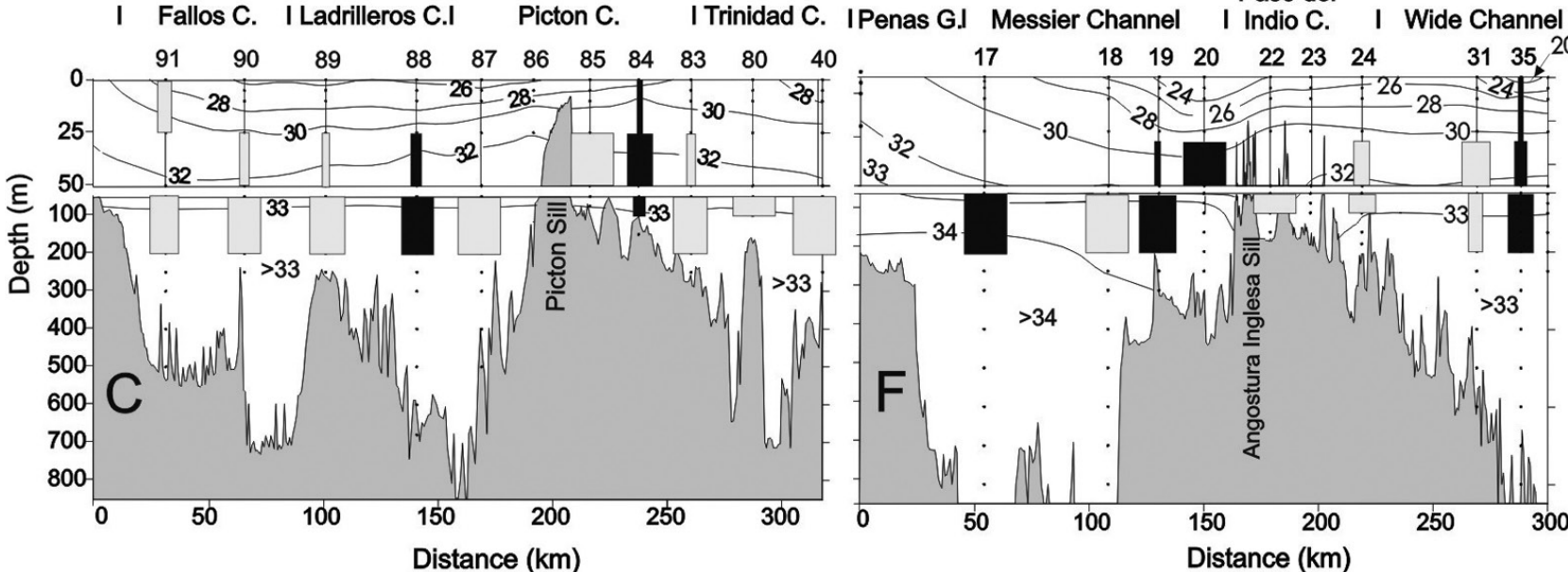

Abundance Scale : $\longmapsto=100 \%$

Fig. 4. - Vertical distribution in spring 2008, of polygastric stages in terms of relative abundances at each station (boxes) and salinity (isolines), in the longitudinal oceanic transect (OT) and estuarine transect (ET). A-B, Muggiaea atlantica; C-D, Lensia conoidea; E-F, Dimophyes arctica. Grey boxes, diurnal tows; black boxes, nocturnal tows.

low $50 \mathrm{~m}$ (Fig. 4A-B). On the other hand, Lensia conoidea and Dimophyes arctica were more abundant at greater depths, below $50 \mathrm{~m}$ at most stations (Fig. 4C and F). There were non-significant differences between the vertical distributions of polygastric and eudoxid stages of $M$. atlantica between the two transects (Kruskal-Wallis test, $\mathrm{p}>0.05$, Table 3). In contrast, significant differences were obtained between the vertical distributions of polygastric and eudoxid stages for both $L$. conoidea and D. arctica in both transects (Kruskal-Wallis test, $\mathrm{p}<0.05$, Table 3 ). 
Table 3. - Kruskal-Wallis test for differences in abundances of polygastric and eudoxid stages of the dominant species between the three depth strata in both the oceanic and estuarine transects. Significant values are indicated in bold $(\mathrm{p}<0.05)$.

\begin{tabular}{|c|c|c|c|c|}
\hline & \multicolumn{2}{|c|}{ Oceanic transect } & \multicolumn{2}{|c|}{ Estuarine transect } \\
\hline & Polygastric stage & Eudoxid stage & Polygastric stage & Eudoxid stage \\
\hline Muggiaea atlantica & 0.2653 & 0.8466 & 0.3845 & 0.2398 \\
\hline Lensia conoidea & 0.0089 & 0.0318 & 0.0021 & 0.0026 \\
\hline Dimophyes arctica & 0.0002 & $\mathbf{0 . 0 2 2 7}$ & 0.00007 & 0.00003 \\
\hline
\end{tabular}

\section{Relationships between siphonophores and oceano- graphic conditions}

The relationships between siphonophore abundances and oceanographic variables are presented in a CCA triplot (Fig. 5). The Monte Carlo permutation test indicated significance in the ordination diagram $\left(\mathrm{F}_{\text {ratio }}=2.83, \mathrm{p}<0.001\right)$, in which the first two axes explained $98.9 \%$ of the total variance $(83.8 \%$ in the first axis and $15.1 \%$ in the second axis). Axis one was positively correlated with depth strata and salinity, and negatively correlated with dissolved oxygen and temperature. This indicated an increase in salinity and depth strata from left to right in the diagram (Fig. 5), mainly evidenced at the deepest sampling stations (50$200 \mathrm{~m}$ ). The species coupling with these environmental conditions in the deepest stratum were Muggiaea bargmannae, Lensia conoidea, L. meteori, L. subtilis, Pyrostephos vanhoeffeni, Sphaeronectes koellikeri and Dimophyes arctica (Fig. 5). On the other hand, the species associated with the shallower stratum, lower salin- ity and higher oxygen were Chelophyes appendiculata and Eudoxoides spiralis. At the centre of the diagram, Muggiaea atlantica is located as a dominant species which is not associated with any particular depth stratum, because it was found throughout the water column. The second axis explained a lower fraction of the total variance and was mainly negatively correlated with temperature, indicating an increase in this environmental variable in the shallower strata.

\section{DISCUSSION}

\section{Hydrographic characteristics}

During the CIMAR 14 Fiordos cruise, the temperature was nearly homogeneous over the whole water column along both longitudinal transects, which was not the case for salinity, leading to a highly stratified water column (Fig. 2B and E). Therefore, the vertical density structure is governed by the salinity distribution. The vertical distribution of salinity was character-

(Axis 1 and 2: $98.9 \%$ )

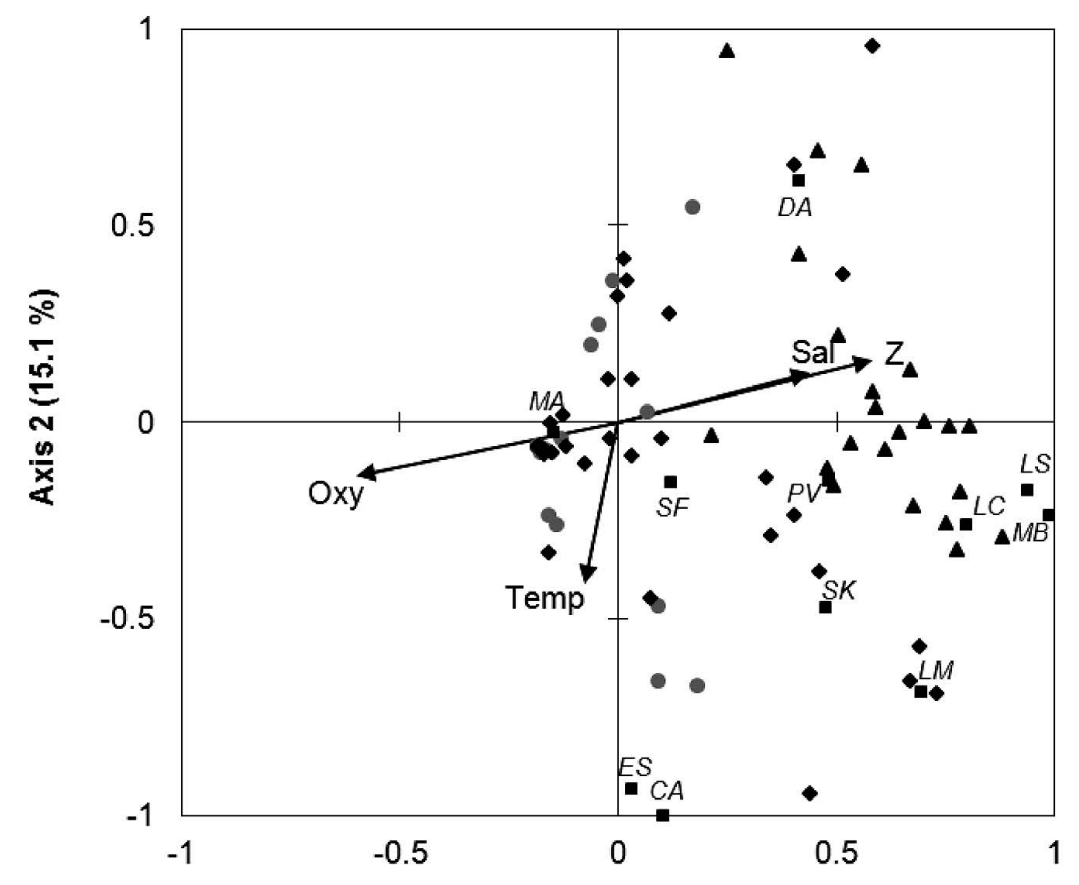

Axis $1(83.8 \%)$

\section{- $0-25 \mathrm{~m}$ - $25-50 \mathrm{~m}$ ^ $50-200 \mathrm{~m}$ - Species $\rightarrow$ Environment}

Fig. 5. - Canonical correspondence analysis triplot based on data from spring 2008 showing scores of sampling sites by depth strata, the 11 most abundant siphonophore species and oceanographic variables. MA, Muggiaea atlantica; LC, Lensia conoidea; DA, Dimophyes arctica; PV, Pyrostephos vanhoeffeni; LM, Lensia meteori; SK, Sphaeronectes koellikeri; SF, Sphaeronectes fragilis; LS, Lensia subtilis; ES, Eudoxoides spiralis; MB, Muggiaea bargmannae; CA, Chelophyes appendiculata; Z, depth strata; Temp, temperature; Sal, salinity; Oxy, dissolved oxygen. 
ized by two layers: a surface layer ( 0 to $\sim 30-50 \mathrm{~m}$ ), and a deeper layer (30-50 $\mathrm{m}$ to the bottom) including a strong vertical salinity gradient and therefore a pycnocline. The vertical stratification was less intense at both the northern and southern oceanic ends and more intense at the centre of the transects (Fig. 2B and E), where the freshwater input from continental rivers and glacial melting is greater (Silva and Calvete 2002, Sievers et al. 2002). The freshwater input in the ET and at the heads of Baker and Eyre fjords is greater, due to the input from continental rivers, rain and melting water. This explains the lower salinities (20-32) in the surface layer of the ET, compared with the low salinities (26-32) along the OT, which receives mainly rainwater input. Below the highly stratified surface layer, a marine, saltier (33-34) deep layer is present $(\sim 50 \mathrm{~m}$ to the bottom), and is less variable and almost homohaline (Fig. 2B and E).

The surface layers $(0-50 \mathrm{~m})$ of the Baker and Eyre Fjords and along both longitudinal transects were well oxygenated, generally above $6 \mathrm{~mL} \mathrm{~L}^{-1}$ (>90\% saturation; Fig. 2C and F), due to photosynthetic processes (Aracena et al. 2011) and ocean-atmosphere oxygen exchange. Beneath the highly oxygenated surface layer, dissolved oxygen concentrations dropped below $4 \mathrm{~mL} \mathrm{~L}^{-1}$ ( $<50 \%$ saturation), presumably due to consumption caused by the degradation of autochthonous and allochthonous particulate organic matter coming from the surface layer and river discharge (Silva 2008). Similar low dissolved oxygen concentrations (3-4 mL $\mathrm{L}^{-1}$ ) have been recorded previously in the area (Silva and Calvete 2002).

Subantarctic Water (SAAW) from the adjacent $\mathrm{Pa}$ cific Ocean penetrates into the region through the Gulf of Penas and Trinidad Strait, giving the marine characteristics to the deeper layers. As the SAAW spreads into the channels and fjords, it mixes with freshwater (FW) in different proportions (Sievers and Silva 2008). The water formed of salinities between 31 and 33 is known as Modified Subantarctic Water (MSAAW) or if fresher (2-31) it is known as Estuarine Water (EW). The EW remains in the surface layer and the MSAAW fills the subsurface and deeper layers of the interior fjords.

\section{Siphonophore community composition and hori- zontal distribution}

Results from spring 2008 were similar to those of spring 1996 (Palma et al. 1999), with 8 out of the 12 presently identified species overlapping (Table 4). The nine rare species that were recorded, representing $4.2 \%$ of the total number of siphonophores caught, were collected in estuarine interior waters and included some species found widely in oceanic waters, such as $E u$ doxoides spiralis, Chelophyes appendiculata, Lensia subtilis and Praya dubia (Totton 1965, Pugh 1999). However, it is supposed that the extreme oceanographic characteristics of these interior waters would be detrimental for the maintenance of reproducing populations. In general, all the identified species were epipelagic species, including some species abundant in Antarctic waters, such as Dimophyes arctica, Muggiaea bargmannae and Pyrostephos vanhoeffeni (Pagès et al. 1994, Pugh et al. 1997), and some species from warm and temperate oceanic waters (the remaining species), which may enter through the Gulf of Penas and the Ladrillero and Trinidad Channels. Their shallow sills (Ladrillero and Trinidad $\sim 50 \mathrm{~m}$, and Penas $\sim 150 \mathrm{~m}$ ) would prevent the entrance of mesopelagic species into interior waters.

$M$. bargmannae is a bipolar species mainly collected in boreal waters (Totton 1965, Pugh 1999). This finding represents the first record for Chilean waters, thus increasing the biodiversity of siphonophores known from the southeastern Pacific. The number of siphonophore species reported in the southern fjords ecosystem has therefore increased from the 14 previously recorded species (Palma and Silva 2004, Palma et al. 2007a, 2011, Villenas et al. 2009) to 17 species. However, the southern Chilean Patagonian fjords exhibit a lower diversity of siphonophores than the Humboldt Current System, where 54 species have been recorded (Palma 1977, 1994, Palma and Rosales 1995, Pagès et al. 2001, Palma and Apablaza 2004, Apablaza and Palma 2006, Pavez et al. 2010), and than the global ocean, where almost 190 species have been recorded (Pugh 1999, Boltovskoy et al. 2005). In any event, the

Table 4. - Summary of basic statistics for polygastric stages of siphonophores between the springs of 1996 (CIMAR 2 Fiordos cruise) and 2008 (CIMAR 14 Fiordos cruise). Total number of individuals, range of abundances, average abundance per station, standard deviation (SD), dominance (D) and occurrence (O). Abundances are expressed as number of individuals per $1000 \mathrm{~m}^{-3}$. Ne, nectophores.

\begin{tabular}{|c|c|c|c|c|c|c|c|c|c|c|c|c|}
\hline \multirow[b]{2}{*}{ Species } & \multicolumn{6}{|c|}{ Spring 1996} & \multicolumn{6}{|c|}{ Spring 2008} \\
\hline & Total & $\begin{array}{c}\text { Range of } \\
\text { non-zero } \\
\text { abundances }\end{array}$ & $\begin{array}{l}\text { Average } \\
\text { per sta- } \\
\text { tion }\end{array}$ & SD & $\mathrm{D}(\%)$ & $\mathrm{O}(\%)$ & Total & $\begin{array}{c}\text { Range of } \\
\text { non-zero } \\
\text { abundances }\end{array}$ & $\begin{array}{l}\text { Average } \\
\text { per sta- } \\
\text { tion }\end{array}$ & SD & $\mathrm{D}(\%)$ & $\mathrm{O}(\%)$ \\
\hline$\overline{\text { Muggiaea atlantica }}$ & 11476 & $3-3613$ & 337.5 & 706.4 & 67.51 & 88.2 & 120761 & $14-38174$ & 3551.8 & 7599.6 & 79.82 & 100.0 \\
\hline Lensia conoidea & 5104 & $4-1547$ & 150.1 & 301.6 & 30.02 & 79.4 & 12813 & $6-3500$ & 376.8 & 627.7 & 8.47 & 88.2 \\
\hline Dimophyes arctica & 168 & $3-47$ & 4.9 & 8.9 & 0.99 & 44.1 & 11675 & $13-2685$ & 343.4 & 551.7 & 7.72 & 88,2 \\
\hline Pyrostephos vanhoeffeni (ne) & 3 & $1-1$ & 0.1 & 0.0 & 0.02 & 8.8 & 2459 & $1-427$ & 72.3 & 115.0 & 1.63 & 73.5 \\
\hline Lensia meteori & 166 & $3-57$ & 4.9 & 13.5 & 0.98 & 23.5 & 1486 & $4-419$ & 43.7 & 95.6 & 0.98 & 58.8 \\
\hline Sphaeronectes koellikeri & 47 & $6-25$ & 1.4 & 4.6 & 0.28 & 11.8 & 786 & $5-289$ & 23.1 & 68.8 & 0.52 & 23.5 \\
\hline Eudoxoides spiralis & 29 & $8-21$ & 0.9 & 3.8 & 0.17 & 5.9 & 267 & $9-107$ & 7.8 & 21.8 & 0.18 & 17.6 \\
\hline Chelophyes appendiculata & 6 & $1-6$ & 0.2 & 1.0 & 0.04 & 2.9 & 13 & $2-13$ & 0.4 & 2.3 & 0.01 & 2.9 \\
\hline Abylopsis tetragona & 18 & $1-3$ & 0.5 & 1.1 & 0.11 & 17.7 & 0 & 0 & 0 & 0 & 0 & 0 \\
\hline Sphaeronectes fragilis & 0 & 0 & 0 & 0 & 0 & 0 & 627 & $4-228$ & 18.5 & 50.6 & 0.41 & 29.4 \\
\hline Lensia subtilis & 0 & 0 & 0 & 0 & 0 & 0 & 391 & $13-186$ & 11.5 & 41.3 & 0.26 & 11.7 \\
\hline Muggiaea bargmannae & 0 & 0 & 0 & 0 & 0 & 0 & 21 & $2-21$ & 0.6 & 3.6 & 0.01 & 2.9 \\
\hline Praya dubia & 0 & 0 & 0 & 0 & 0 & 0 & 9 & $1-1$ & 0,3 & 1.2 & 0.01 & 5.9 \\
\hline Total & 170175 & & & & & & 151288 & & & & & \\
\hline
\end{tabular}


low diversity detected in Chilean fjords and channels has also been reported for Norwegian fjords (Båmstedt 1988, Hosia and Båmstedt 2007).

The high abundance of Muggiaea atlantica was particularly noteworthy. It is a eurythermic and euryhaline species, widely distributed in both the adjacent oceanic SAAW and the interior MSAAW and EW throughout the study area. Both polygastric and eudoxid stages abundances were highest in the ET, particularly in the Wide Channel and Eyre Fjord (Table 2). We hypothesize that the high tolerance of $M$. atlantica to the temperature and salinity gradients favours its reproductive success in interior waters, where it is the dominant siphonophore species in the fjords of southern Chile (Pagès and Orejas 1999, Palma et al. 1999, 2007a, 2011, Palma and Aravena 2001, Villenas et al. 2009). M. atlantica is common in neritic zones and represents the predominant siphonophore along the coast of Chile, where it forms dense coastal aggregations in spring and summer (Palma 1977, 1994, Palma and Rosales 1995, Ulloa et al. 2000, Palma and Apablaza 2004, Apablaza and Palma 2006). M. atlantica occurs widely in coastal and shelf waters from warm and temperate regions in the Pacific, Atlantic and Indian Oceans, and the Mediterranean Sea (Alvariño 1971). It is also very frequent in areas of high productivity such as upwelling ecosystems like the Benguela Current (Pagès and Gili 1992) and the Humboldt Current (Palma and Rosales 1995, Palma and Silva 2004, Pavez et al. 2010).

Lensia conoidea and Dimophyes arctica occurred at much lower densities than M. atlantica, and their highest densities were found in the OT (Table 2), where SAAW waters were dominant. Only some polygastric stages of $L$. conoidea were collected in the Gulf of Penas and eudoxids were not found there at all (Fig. 3E). On the other hand, a larger abundance of the polygastric stages of $D$. arctica occurred, although eudoxids were extremely scarce. The spatial distribution of eudoxids for both species was shifted towards MSAAW and EW with lower temperatures $\left(<6^{\circ} \mathrm{C}\right)$ and salinities $(<30)$ (Silva and Calvete 2002), a situation even clearer in the Eyre Fjord, where the highest densities of eudoxids were found (Fig. 3F).

L. conoidea is common and abundant in the great oceans, particularly in the California and Benguela currents, and in the Mediterranean Sea (Alvariño 1971), spanning a broad depth distribution from the surface down to the bathypelagic zone (Pagès and Gili 1992). D. arctica is a cosmopolitan species with a bipolar distribution, inhabiting the great oceans as well as the Antarctic, Arctic, and Mediterranean Sea (Alvariño 1971). In boreal and austral latitudes it is more abundant in epipelagic waters than in tropical and temperate waters, where it is more common in meso- and bathypelagic waters (Pagès and Gili 1992).

It is interesting to note that the dominant siphonophores (M. atlantica, Lensia conoidea and Dimophyes arctica) found in these Patagonian fjords have also been found in fjords in the northern hemisphere, such as the Norwegian fjords Fanasfjord, Korsfjord and Hardangerfjord (Bakke and Sands 1977; Pagès et al. 1996). Though $M$. atlantica has been found sporadi- cally, it appeared in large numbers during the warmer than average year of 2002 in Fanafjord (Fossa et al. 2003), which had received high salinity waters from the Atlantic Ocean (Hosia and Bamsted 2007, 2008). In the Korsfjord Fjord, an abundance of polygastric stages of both Lensia conoidea and Dimophyes arctica has been found throughout the year, with the maximum abundance being reached in spring (late May to early June) (Hosia and Bamsted 2008).

\section{Vertical distribution}

The presence of a strong pycnocline at around 50 m depth, separating the EW from the MSAAW, had an important effect on the vertical distribution of $M$. atlantica, concentrating the polygastric and eudoxid populations in the upper $50 \mathrm{~m}$, where the more stable, oxygenated, low-salinity layer of the water column occurred (Fig. 4A-B). L. conoidea and D. arctica, on the other hand, for which the polygastric and eudoxid populations also coexisted, were distributed in deeper waters (below $50 \mathrm{~m}$ ) where quasi-homogeneous conditions for temperature, salinity and dissolved oxygen occurred (Fig. 4C and F). The results of a Kruskal-Wallis test indicated that these species had a significantly different depth distribution, being deeper $(>50 \mathrm{~m})$ in both OTs and ETs $(p<0.05$; Table 3$)$. The difference in the use of the water column suggests that $M$. atlantica has different ecological requirements to $L$. conoidea and D. arctica. The diel vertical distribution of this species could not be studied, because day and nighttime samplings were never performed at the same stations.

The vertical distribution pattern of some dominant siphonophore species (Lensia conoidea, Dimophyes arctica and Pyrostephos vanhoeffeni) was such that their presence and higher abundances were associated with the deeper (50-200 m) stratum: CCA plots showed a clear separation between the shallower (0-25 $\mathrm{m}$ and 25-50 $\mathrm{m}$ ) and deeper strata. The CCA indicated that a relatively large proportion of amongsite variances in the abundance of these three species among the sampling stations were positively correlated with depth strata and salinity, and negatively with dissolved oxygen and temperature. This is an expected association, because as depth increases so does the salinity, and the temperature and dissolved oxygen concentration decrease (Fig. 2). The oceanographic conditions in the deeper stratum where three species were most abundant are characteristic of the MSAAW water masses. The CCA also demonstrated that $M$. atlantica, the most dominant species, was mainly associated with high dissolved oxygen and low salinity in surface layers. However, the low correlation also indicates that $M$. atlantica can be distributed throughout the water column (Palma et al. 2011). The canonical analysis also indicated that $L$. subtilis and $M$. bargmannae abundances were correlated with the deeper stratum with high salinity and low dissolved oxygen concentrations. E. spiralis and C. appendiculata were found in shallow and warm waters, probably associated with the influence of oceanic waters. Rare species such as L. meteori and S. koellikeri were 
correlated with the deeper stratum with higher salinity and temperatures.

\section{Comparison between the results obtained in spring 1996 and 2008}

Species richness in spring 1996 was $75 \%$ of that found in spring 2008 (see Palma et al. 1999), with Muggiaea bargmannae, Lensia subtilis, Praya dubia and Sphaeronectes fragilis being found for the first time in this area (9 and 12 species in 1996 and 2008, respectively). The average abundance per station for siphonophores was almost one order of magnitude higher in 2008 (Table 4). This trend was observed for most species, except for $L$. conoidea, whose average abundance per station was only 2-3 times higher in 2008. The most significant increases were observed in $M$. atlantica and D. arctica (Table 4). Moreover, $D$. arctica, which was a very rare species comprising less than $1 \%$ of the total number of siphonophores in spring 1996 , comprised $7.7 \%$ of the total number of siphonophores in spring 2008, with a wide geographic distribution of both polygastric and eudoxid stages in the same area (Fig. 3C-F).

The results obtained in the spring of 1996 indicated that the community of siphonophores was mainly dominated by $M$. atlantica $(67.51 \%)$ and L. conoidea $(30.02 \%)$, while $D$. arctica $(0.99 \%)$ was almost absent. However, in spring 2008, a high dominance of $M$. atlantica $(80.37 \%)$ compared with L. conoidea $(8.53 \%)$ and $D$. arctica $(7.77 \%)$ was evident (Table 4$)$. The large increase in the relative abundance of $M$. atlantica observed in different areas of the southern Chilean fjords ecosystem (Palma et al. 2007a, 2011, Villenas et al. 2009) confirms its high adaptability to areas of low water temperature and salinity, where the highest densities of its eudoxid phase were concentrated (Fig. 3D). In fact, in spring 1996 the highest densities were found in ocean channels (OT, Fallos and Ladrillero Channels), while in spring 2008 a peak of abundance was found in EWs with lower temperature and salinity (ET, Messier Channel and Eyre Fjord). This species has become the dominant species in the Chilean fjords ecosystem, where it has achieved considerable reproductive success.

This increase in abundance cannot be explained on the basis of inter-annual differences in the abiotic variables analysed, as temperature, salinity and dissolved oxygen concentration values recorded in spring 2008 were similar to those recorded in spring 1996 by Silva and Calvete (2002). The increase may be the result of the different sampling gear used. In November 1996, integrated oblique tows (0-200 m) were carried out using bongo nets $\left(0.28-\mathrm{m}^{2}\right.$ mouth opening and $350-\mu \mathrm{m}$ mesh size), while in November 2008 the oblique tows were performed at three depth levels (0-200 m) using Tucker trawl nets with a much larger mouth opening ( $1 \mathrm{~m}^{2}, 350-\mu \mathrm{m}$ mesh size). The capture results were standardised according to the volumes filtered by each net (ind $1000 \mathrm{~m}^{-3}$ ) but, according to Pepin and Shears (1997), the large sample volume of the Tucker trawl relative to the bongo nets can result in significantly higher estimates of species diversity for fish eggs and larvae but not for crustaceans or medusae. Therefore, the differences may actually be due to a higher abundance of gelatinous organisms in interior waters, especially for $M$. atlantica, a situation also observed in other areas of the interior water region in southern Chile (Palma et al. 2007a, 2011, Villenas et al. 2009).

\section{FINAL REMARKS}

A total of 12 species were recorded, of which Muggiaea bargmannae, Lensia subtilis, Praya dubia and Sphaeronectes fragilis were identified for the first time in the central Patagonian fjords. M. bargmannae represents a new record for the southeastern Pacific. The most common and abundant species in Chilean Central Patagonian fjords were Muggiaea atlantica (78.6\% of total), Lensia conoidea $(8.7 \%)$ and Dimophyes arctica $(8.5 \%)$. M. atlantica, the dominant species, was present at high relative abundances in EW (ET, 90.7\%), while L. conoidea and D. arctica were principally collected in oceanic waters (OT, 32.5\% and $16.0 \%$, respectively) (Table 2). The eudoxids of these species followed the same horizontal distribution patterns as their polygastric stages. These distributions allowed us to hypothesize that salinity and dissolved oxygen vertical gradients play an important role in determining the depth distribution patterns of some of the siphonophore species. This is in agreement with results reported for many species of gelatinous zooplankton from the northern hemisphere, which are distributed in different water column strata of varying thickness, also reflecting the physical/chemical structure of the water column (i.e. Graham et al. 2001, Raskoff et al. 2005).

\section{ACKNOWLEDGEMENTS}

This investigation was supported by the Comite Oceanográfico Nacional (CONA), Chile, through the projects CONA-C14F 08-08 granted to Sergio Palma and CONA-CF14 08-13 granted to Nelson Silva. The authors thank Dr. Leonardo Castro, who facilitated the sampling of zooplankton. We also thank María Inés Muñoz, who was in charge of all zooplankton sampling at sea, as well as Paola Reinoso, who performed the dissolved oxygen analysis onboard the R/V Vidal Gormaz. The valuable comments by two anonymous reviewers are also appreciated.

\section{REFERENCES}

Alvariño A. 1971. Siphonophores of the Pacific with a review of the world distribution. Bull. Scripps Inst. Oceanogr. 16: 1432.

Apablaza P. Palma, S. 2006. Efecto de la zona de mínimo oxígeno sobre la migración vertical de zooplancton gelatinoso en la bahía de Mejillones. Invest. Mar., Valparaíso 34(2): 81-95.

Aracena C., Lange C.B., Iriarte J.L., et al. 2011. Latitudinal patterns of export production recorded in surface sediments of the Chilean Patagonian fjords $\left(41-55^{\circ} \mathrm{S}\right)$ as a response to water column productivity. Cont. Shelf Res. 31(3-4): 340-355. http://dx doi.org/10.1016/j.csr.2010.08.008

Bakke J.L.W., Sands N.J. 1977. Hydrographical studies in Korsfjorden, western Norway, in the period 1972-1977. Sarsia 63: 7-16.

Båmstedt U. 1988. The macrozooplankton community of Kosterf- 
jorden, western Sweden. Abundance, biomass and preliminary data on the cycles of dominant species. Sarsia 73: 107-124.

Boltovskoy D., Correa N., Boltovskoy A. 2005. Diversity and endemism in cold waters of the South Atlantic: contrasting patterns in the plankton and the benthos. In: Arntz W.E., Lovrich G.A., Thatje S. (eds). The Magellan Antarctic connection: links and frontiers at high southern latitudes. Sci. Mar. 69(Suppl. 2): $17-26$.

Bravo V., Palma S., Silva S. 2011. Seasonal and vertical distributional patterns of medusae in Aysén region, southern Chile. Lat. Am. J. Aquat. Res. 39(2): 359-377. http://dx.doi.org/10.3856/vol39-issue2-fulltext-17

Brodeur R., Sugisaki H., Hunt, G. 2002. Increases in jellyfish biomass in the Bering Sea: implications for the ecosystem. Mar Ecol. Prog. Ser. 233: 89-103. http://dx.doi.org/10.3354/meps233089

Buschmann A.H., Riquelme V.A., Hernández-González M.C., et al. 2006. A review of the impacts of salmonid farming on marine coastal ecosystems in the southeastern Pacific. ICES J. Mar. Sci. 63: 1338-1345. http://dx.doi.org/10.1016/j.icesjms.2006.04.021

Bustos C.A., Landaeta M.F. Balbontín F. 2011. Ichthyoplankton spatial distribution and its relation with water column stratification in fjords of southern Chile $\left(46^{\circ} 48^{\prime}-55^{\circ} 09^{\prime} \mathrm{S}\right)$ in austral spring 1996 and 2008. Cont. Shelf Res. 31(3-4): 393-303. http://dx.doi.org/10.1016/j.csr.2010.03.013

Calvete C., Sobarzo M. 2011. Quantification of the surface brackish water layer and frontal zones in southern Chilean fjords between Boca del Guafo (431 ${ }^{\circ} 30^{\prime}$ 'S) and Estero Elefantes (46³0’S) Cont. Shelf Res. 31(3-4): 162-171. http://dx.doi.org/10.1016/j.csr.2010.09.013

Fossa J.H., Flood P.R., Olsen A.B., et al. 2003. Sma of usynlige, men plagsomme maneter av arten Muggiaea atlantica. Havets Miljo, pp. 99-103.

Graham W.M., Pagès F., Hammer W.M. 2001. A physical context for gelatinous zooplankton aggregations: a review. Hydrobiologia 451: 199-212. http://dx.doi.org/10.1023/A:1011876004427

Hosia A., Båmstedt U. 2007. Seasonal changes in the gelatinous zooplankton community and hydromedusa abundances in Korsfjord and Fanafjord, western Norway. Mar. Ecol. Prog. Ser. 351: 113-127. http://dx.doi.org/10.3354/meps07148

Hosia A., Båmstedt U. 2008. Seasonal abundance and vertical distribution of siphonophores in western Norwegian fjords. J. Plankton Res. 30(8): 951-962. http://dx.doi.org/10.1093/plankt/fbn045

Mackie G.O., Pugh P.R., Purcell J.E. 1987. Siphonophore biology. Adv. Mar. Sci. 24: 97-262.

Mills C. 2001. Jellyfish blooms: are populations increasing globally in response to changing ocean conditions? Hydrobiology 451: 55-68. http://dx.doi.org/10.1023/A:1011888006302

Mujica A., Medina M. 2000. Distribución y abundancia de larvas de crustáceos decápodos en el zooplancton de los canales australes. Proyecto Cimar-Fiordo 2. Cienc. Tecnol. Mar 23: 49-68.

Pagès F., Gili J.-M. 1992. Siphonophores (Cnidaria, Hydrozoa) of the Benguela Current (southeastern Atlantic). In: Pages F., Gili J.-M., Bouillon J. (eds), Planktonic cnidarians of the Benguela Current. Sci. Mar. 56(Suppl. 1): 65-112.

Pagès F., Orejas C. 1999. Medusae, siphonophores and ctenophores of the Magellan region. In: Arntz W.E., Rios C. (eds), Magellan-Antarctic: ecosystems that drifted apart. Sci. Mar. 63(Suppl. 1): 51-57.

Pagès F., Pugh P.R., Gili J.M. 1994. Macro- and megaplanktonic cnidarians collected in the eastern part of the Weddell gyre during summer 1979. J. Mar. Biol. Assoc. U.K. 74: 873-894.

Pagès F., Gonzalez H.E., Gonzalez S.R. 1996. Diet of the gelatinous zooplankton in Hardangerfjord (Norway) and potential predatory impact by Aglantha digitale (Trachymedusae). Mar. Ecol. Prog. Ser. 139: 69-77. http://dx.doi.org/10.3354/meps 139069

Pagès F., González H., Ramón M., et al. 2001. Gelatinous zooplankton assemblages associated with water masses in the Humboldt Current System, and potential predatory impact by Bassia bassensis (Siphonophora: Calycophorae). Mar. Ecol. Prog. Ser. 210: 13-24. http://dx.doi.org/10.3354/meps 210013

Palma S. 1977. Contribución al estudio de los sifonóforos encontrados frente a la costa de Valparaíso. Aspectos ecológicos. Me- morias Segundo Simposio Latinoamericano de Oceanografía Biológica. Cumaná, Venezuela, Vol. 2: 119133.

Palma S. 1994. Composición y distribución del macroplancton gelatinoso recolectado frente a la costa central de Chile. Rev. Biol. Mar., Valparaíso 29(1): 2345.

Palma S., Apablaza P. 2004. Abundancia estacional y distribución vertical del zooplancton gelatinoso carnívoro en un área de surgencia en el norte del Sistema de la Corriente de Humboldt. Invest. Mar., Valparaíso 32(1): 49-70.

Palma, S., Aravena G. 2001. Distribución de sifonóforos, quetognatos y eufáusidos en la región magallánica. Cienc. Tecnol. Mar, 24: 47-59.

Palma S., Rosales S. 1995. Composición, abundancia y distribución estacional del macroplancton de la bahía de Valparaíso. Invest. Mar., Valparaíso 23: 49-66.

Palma S., Silva N. 2004. Distribution of siphonophores, chaetognaths and euphausiids and oceanographic conditions in the fjords and channels of southern Chile. Deep-Sea Res. II 51(69): 513-535. http://dx.doi.org/10.1016/j.dsr2.2004.05.001

Palma S., Ulloa R., Linacre L. 1999. Sifonóforos, quetognatos y eufáusidos de los canales australes entre el golfo de Penas y estrecho de Magallanes. Cienc. Tecnol. Mar 22: 111-142.

Palma S., Apablaza P., Soto D. 2007a. Diversity and aggregation areas of planktonic cnidarians to the southern channels of Chile (Boca del Guafo to Pulluche Channel). Invest. Mar., Valparaíso 35(2): 71-82.

Palma S., Apablaza P., Silva N. 2007b. Hydromedusae (Cnidaria) of the Chilean southern channels (from Corcovado Gulf to Pulluche-Chacabuco Channels). Sci. Mar. 71(1): 65-74. http://dx.doi.org/10.3989/scimar.2007.71n165

Palma S., Silva N., Retamal M.C., et al. 2011. Seasonal and vertical distributional patterns of siphonophores and medusae in the Chiloé inland sea, Chile. Cont. Shelf Res. 31(3-4): 260-271. http://dx.doi.org/10.1016/j.csr.2010.04.007

Pavez M.A., Landaeta M.E., Castro L.R., et al. 2010. Distribution of carnivorous gelatinous zooplankton in the upwelling zone of central Chile (austral spring 2001). J. Plankton Res. 32(7): 1051-1065. http://dx.doi.org/10.1093/plankt/fbq029

Pepin P., Shears T.H. 1997. Variability and capture efficiency of bongo and Tucker trawl samplers in the collection of ichthyoplankton and other macrozooplankton. Can. J. Fish. Aquat. Sci. 54(4): 765-773. http://dx.doi.org/10.1139/f96-347

Pugh P. 1999. Siphonophorae. In: Boltovskoy D. (ed). South Atlantic zooplankton. Backhuys Publishers, Leiden, pp. 467-511.

Pugh P.R., Pagès, F., Boorman, B. 1997. Vertical distribution and abundance of pelagic cnidarians in the Eastern Weddell Sea, Antarctica. J. Mar. Biol. Assoc. U.K. 77: 341-360. http://dx.doi.org/10.1017/S002531540007171X

Purcell J.E., Uye S., Lo W.T. 2007. Anthropogenic causes of jellyfish blooms and their direct consequences for humans: a review. Mar. Ecol. Prog. Ser. 350: 153-174 http://dx.doi.org/10.3354/meps07093

Raskoff K.A., Purcell J.E., Hopcroft R.R. 2005. Gelatinous zooplankton of the Arctic Ocean: in situ observations under the ice. Polar Biol. 28: 207-217. http://dx.doi.org/10.1007/s00300-004-0677-2

Rosenberg P., Palma S. 2003. Cladóceros de los fiordos y canales patagónicos localizados entre el golfo de Penas y el estrecho de Magallanes. Invest. Mar., Valparaíso 30(1): 15-24.

Sievers H., Silva N. 2008. Water masses and circulation in austral Chilean channels and fjords. In: Silva N., Palma S. (eds). Progress in the oceanographic knowledge of Chilean interior waters, from Puerto Montt to Cape Horn. Comité Oceanográfico Nacional-Pontificia Universidad Católica de Valparaíso, Valparaíso, pp. 53-58.

Sievers H., Calvete C., Silva N. 2002. Distribución de características físicas masas de agua y circulación general para algunos canales australes entre el golfo de Penas y el estrecho de Magallanes (Crucero Cimar Fiordo 2). Cienc. Tecnol. Mar 25(2): 17-43.

Silva N. 2008. Dissolved oxygen, pH, and nutrients in the austral Chilean channels and fjords. In: Silva N., Palma S. (eds). Progress in the oceanographic knowledge of Chilean interior waters, from Puerto Montt to Cape Horn. Comité Oceanográfico Nacional-Pontificia Universidad Católica de Valparaíso, Valparaíso, pp. 37-43.

Silva N., Calvete C. 2002. Características oceanográficas físicas y químicas de canales australes chilenos entre el golfo de Penas 
y el estrecho de Magallanes (Crucero Cimar Fiordo 2). Cienc. Tecnol. Mar 25(1): 23-88.

Silva N., Palma S. (eds). 2008. Progress in the oceanographic knowledge of Chilean interior waters, from Puerto Montt to Cape Horn. Comité Oceanográfico Nacional-Pontificia Universidad Católica de Valparaíso, Valparaíso, 161 pp.

Ter Braak C.J.F., Verdonschot P.F.M. 1995. Canonical correspondence-analysis and related multivariate methods in aquatic ecology. Aquat. Sci. 57: 255-289. http://dx.doi.org/10.1007/BF00877430

Thibault-Botha D., Lutjeharms J.R.E., Gibbons M.J. 2004. Siphonophore assemblages along the east coast of South Africa: mesoscale distribution and temporal variations. J. Plankton Res. 26(9): 1115-1128. http://dx.doi.org/10.1093/plankt/fbh104

Totton A. 1965. A synopsis of the Siphonophora. British Museum (Natural History), London, 230 pp.

Ulloa R., Palma S., Linacre L., et al. 2000. Seasonal changes in the bathymetric distribution of siphonophores, chaetognaths and euphausiids associated to water masses off of Valparaiso, Chile (Southeast Pacific). In: Farber J. (ed). Oceanography of the Eastern Pacific. Centro de Investigación Científica y de Educación Superior de Ensenada (CICESE), Ensenada, 1: 72-83.

Villenas F., Soto D., Palma S. 2009. Cambios interanuales en la biomasa y biodiversidad de zooplancton gelatinoso en aguas interiores de Chiloé, sur de Chile (Primaveras 2004 y 2005). Rev. Biol. Mar. Oceanogr. 44(2): 309-324. http://dx.doi.org/10.4067/S0718-19572009000200005 